\title{
Iron and Nickel Carbonyl Formation in Steel Pipes and Its Prevention- Literature Survey
}

\author{
J. Brynestad
}

\section{OAK RIDGE NATIONAL LABORATORY}




\section{DISCLAIMER}

This report was prepared as an account of work sponsored by an agency of the United States Government. Neither the United States Government nor any agency Thereof, nor any of their employees, makes any warranty, express or implied, or assumes any legal liability or responsibility for the accuracy, completeness, or usefulness of any information, apparatus, product, or process disclosed, or represents that its use would not infringe privately owned rights. Reference herein to any specific commercial product, process, or service by trade name, trademark, manufacturer, or otherwise does not necessarily constitute or imply its endorsement, recommendation, or favoring by the United States Government or any agency thereof. The views and opinions of authors expressed herein do not necessarily state or reflect those of the United States Government or any agency thereof. 


\section{DISCLAIMER}

Portions of this document may be illegible in electronic image products. Images are produced from the best available original document. 
Printed in the United States of America: Available from National Technical Information Service

U.S. Department of Commerce

5285 Port Royal Road, Springfield, Virginia 22161

Price: Printed Copy \$2; Microfiche \$2.25

This report was prepared as an account of work sponsored by the United States Government. Neither the United States nor the Energy Research and Development Administration/United States Nuclear Regulatory Commission, nor any of their employees, nor any of their contractors, subcontractors, or their employees, makes any warranty, express or implied, or assumes any legal liability or responsibility for the arrurary. rnmpleteness or usefulness of anv information. apparatus. product or process disclosed, or represents that its use would not infringe privately owned rights. 
ORNL/TM-5499

Distribution

Category UC-90d

Contract No. W-7405-eng-26

METALS AND CERAMICS DIVISION

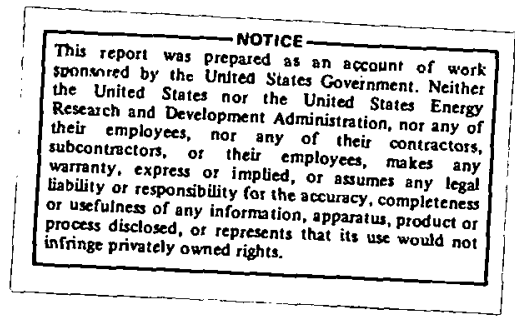

IRON AND NICKEL CARBONYL FORMATION

IN STEEL PIPES AND ITS PREVENTION LITERATURE SURVEY

J. Brynestad

Date Published: September 1976

NOTICE This document contains information of a preliminary nature and was prepared primarlly for internat use at the Oak Ridge National

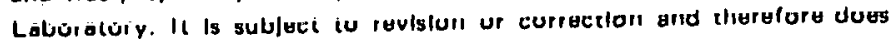
not represent a final report.

OAK RIDGE NATIONAL LABORATORY

Oak Ridge, Tennessee 37830

operated by

UNION CARBIDE CORPORATION

for the

ENERGY RESEARCH AND DEVELOPMENT ADMINISIKATION 
THIS PAGE

\section{ẈAS INTENTIONALLY \\ LEFT BLANK}


CONTENTS

ABSTRACT . . . . . . . . . . . . . . . . . . . . 1

1. INTRODUCTION . . . . . . . . . . . . . . . . . 1

2. THERMODYNAMIC DATA . . . . . . . . . . . . . . . . 2

2.1. IRON PENTACARBONYL . . . . . . . . . . . . 2

2.1.1. Vapor Pressure . . . . . . . . . . . 3

2.1.2. Thermodynamic Functions ........... 3

2.2. NICKEL TETRACARBONYL . . . . . . . . . . . 4

2.2.1. Vapor Pressure . . . . . . . . . . . 4

2.2,2. Thermodynamic Functions ........... 5

3. KINETIC DATA . . . . . . . . . . . . . . 6

4. QUANTITATIVE ANALYTICAL METHODS FOR THE DETERMINATION OF SMALL AMOUNTS OF IRON AND NICKEL CARBONYL IN GASES . . . . 11

5. PREVENTION METHODS . . . . . . . . . . . . . . . 13

6. CONCLUSIONS. . . . . . . . . . . . . . . . . 14

REFERENCES . . . . . . . . . . . . . . . . . . 15 
IRON AND NICKEL CARBONYL FORMATION

IN STEEL PIPES AND ITS PREVENTION LITERATURE SURVEY

J. Brynestad

ABSTRACT

Data were compiled on the stability and formation rates of iron and nickel carbonyls. The data demonstrate that carbonyl formation in steel pipes is governed largely by kinetics. The rate of carbonyl formation is a function of several factors: temperature, pressure, gas flow rate, gas composition, impurities in the gas, alloy composition, surface conditions, and pretreatment of the surfaces. An evaluation of techniques for detecting iron and nickel carbonyls in gases showed atomic. absorption spectroscopy to be a highly effective ( $1 \mathrm{ppb}$ ), almost instantaneous analytical technique. Carbonyl formation in pipe steels seems to be prevented mainly by the use of steels with high chromium contents, by lining the tubing with copper, or by use of any stable coating that prevents the carbon monoxide from directly contacting the metal.

\section{INTRODUCTION}

A project is under way to determine the kinetics of the formation of iron and nickel carbonyls when carbon monoxide gas, in the presence of hydrogen, contacts structural steels at $100-500^{\circ} \mathrm{F}\left(40-260^{\circ} \mathrm{C}\right)$. The first step in the project is a survey of pertinent literature on related thermodynamics, kinetics, and analytical chemistry. This is the report of that survey.

Iron and nickel carbonyls are formed by the action of carbon monoxide gas upon alloys and ores that contain iron and nickel: The presence of iron and/or nickel carbonyl in process gases may have serious consequences. Apart from their toxicity, these carbonyls may cause problems by the deposition of metal oxides in gas burners, 
by plating out metal at higher temperatures by decomposition, or by the formation of deposits of reaction products between the carbonyls and other impurities in the gases.

Rather little is known in detail about the rate of carbonyl formation under various conditions. It seems to be we11 established, however, that unless special steps are taken to increase the rate of carbonyl formation, the rate of iron carbonyl formation in most cases is so low that thermodynamic equilibrium is not reached.

Information found in the literature pertinent to the formation of iron and nickel carbonyl from pipe steels is surveyed in the following chapters:

2. Thermodynamic data,

3. Kinetic information,

4. Analytical. techniques including our own observations,

5. Possible methods for the prevention of carbonyl formation,

6. Conclusions.

The compilation of literature references is not exhaustive, as this would imply a collection of hundreds of publications that are only marginally informative for this project. Rather, we have tried to minimize the number of publications by including only those with information directly pertinent to the project. By doing this one admittedly runs the risk of omitting material that the individual reader might consider relevant. For example, the preponderance of references to analytical methods for iron and nickel carbonyl has been omitted because they are not sensitive enough for this project. However, Chemical Abstracts and Chemical Tities have been screened up to mid-April 1976.

\section{THERMODYNAMIC DATA}

\subsection{IRON PENTACARBONYL}

Iron pentacarbonyl at room temperature is a viscous, pale yellow liquid. ${ }^{1}$ It crystallizes at about $-20^{\circ} \mathrm{C}$, and at atmospheric pressure boils about $102^{\circ} \mathrm{C}$. It is very toxic. ${ }^{2}$ 


\subsubsection{Vapor Pressure}

The data by Trautz and Badstüber ${ }^{3}$ and by Gilbert and Sulzmann ${ }^{4}$ are in very good agreement. Gilbert and Sulzmann's results for temperatures between -19 and $31^{\circ} \mathrm{C}$ may be expressed as

$$
\begin{aligned}
& \log [p(\mathrm{~Pa})]=-2096.7 / T+10.6208, \\
& \log [p(\text { torr })]=-2096.7 / T+8.4959,
\end{aligned}
$$

where $T$ is in Kelvins. Results by Trautz and Badstüber for temperatures between 0 and $104^{\circ} \mathrm{C}$ may be expressed as

$$
\begin{aligned}
& \log [p(\mathrm{~Pa})]=-2050.7 / T+10.4347, \\
& \log [p(\text { tor } \mathrm{r})]=-2050.7 / T+8.3098 .
\end{aligned}
$$

The critical point is about $285^{\circ} \mathrm{C}$ at about $29.6 \mathrm{~atm},(3.0 \mathrm{MPa})$.

\subsubsection{Thermodynamic Functions}

The thermodynamic equilibrium constant for the equilibrium

$$
\mathrm{Fe}(s)+5 \mathrm{CO}(g) \rightleftharpoons \mathrm{Fe}(\mathrm{CO})_{5}(g)
$$

has been calculated by Ross et al., ${ }^{5}$ Syrkin, ${ }^{6}$ and others. Calculations by Ross et al. give for the equilibrium above [Eq. (3)]:

$$
\log K=8940 / T-30.09
$$

in terms of pressures in atmospheres. Syrkin's data can be written (also in atmospheres) for the equilibrium (3) above.

$$
\text { lug } K^{\prime}=10206 / T-30.42 \text {. }
$$


Pichler and Walenda ${ }^{7}$ also calculated equilibrium constants for Eq. (3). However, their calculations were based on rather inaccurate data; their values for $K$ are about two orders of magnitude larger than those calculated from data of Ross et al.* The same applies to the values given by Brief et al.: ${ }^{8}$

$$
\log K=10900 / T-32.672
$$

which was based on estimates by Cooper et al. ${ }^{9}$ The data of Ross et al. are presumably the most reliable.

As will be discussed in Chap. 3, an accurate knowledge of the equilibrium constant does not give any information as to the rate of formation of iron or nickel carbonyl. It should also be taken into consideration that gas mixtures containing large concentrations of iron or nickel carbonyl will be quite nonideal, so that additional information (or estimates) must be invoked to calculate reliable equilibrium concentrations from thermodynamic data.

\subsection{NICKEL TETRACARBONYL}

Nickel carbonyl at room temperature is a colorless, volatile liquid with extreme toxicity. ${ }^{2}$ It melts at $-17.2^{\circ} \mathrm{C}$ and boils at $42.2^{\circ} \mathrm{C}$ at atmospheric pressure.10,11

\subsubsection{Vapor Presourc}

Walsh's datall for the vapor pressure over liquid nickel tetracarbonyl in the temperature range 0 to $35.1^{\circ} \mathrm{C}$ give

$$
\begin{aligned}
& \log p(\mathrm{~Pa})=10.0092-1578 / T \\
& \log [p(\text { torr })]=7.8843-1578 / T
\end{aligned}
$$

* Note that the way of presenting equilibrium constants used by Pichler and Walenda is the inverse of the conventional presentation. 
This is in good agreement with Suginuma and Satozaki's data ${ }^{10,12}$ in the temperature range 0 to $25^{\circ} \mathrm{C}$ :

$$
\begin{aligned}
& \log p(\text { tor } \mathbf{r})=7.878-1574.49 / T \\
& \log p(\mathrm{P} \dot{a})=10.003-1574.49 / T .
\end{aligned}
$$

The experimental value of the critical temperature ${ }^{i 0}$ lies between 191 and $195^{\circ} \mathrm{C}$.

\subsubsection{Thermodynamic Functions}

The thermodynamic functions for the equilibrium

$$
\mathrm{Ni}(\mathrm{s})+4 \mathrm{CO}(g) \rightleftharpoons \mathrm{Ni}(\mathrm{CO})_{4}(g)
$$

have been evaluated by a number of authors, the most recent being Kipnis and Mikhailova, ${ }^{13}$ who find the most probable values to be:

$$
\begin{aligned}
& \Delta H_{298}^{\circ}=-142.3 \mathrm{~kJ} / \mathrm{mole}=-34.0 \mathrm{kcal} / \mathrm{mole} \\
& \Delta S_{298}^{\circ}=419.2 \mathrm{~J} \mathrm{~mole}{ }^{-1} \mathrm{k}^{-1}=-100.2 \mathrm{e} . \mathrm{u} .
\end{aligned}
$$

If one assumes $\Delta C_{\mathrm{p}}$ to be zero these values give for the equilibrium constant:

$$
\log K=7430 / T-21.90
$$

Ross et al. 5 obtained

$$
\log K=8546 / T-21.64
$$

Equations (10) and (11) imply pressures measured in atmospheres. 
The discrepancy is due to a difference in the assumed value of $\Delta H^{\circ}{ }_{298}$. Experimentally obtained values for $\Delta H^{\circ} 298$ are strongly dependent upon the physical state of the nickel metal used in the experiment, as finely divided nickel uniformly gives higher (absolute) values than compact nickel. Thus Kipnis and Mikhailova's data at present seem to be the most reliable.

\section{KINETIC DATA}

As early as 1891 Roscoe and Scudder ${ }^{14}$ had reported that water gas at room temperature and $0.8 \mathrm{MPa}$ ( 8 atm.) pressure in a carbon steel cylinder reacted with the cylinder walls to form iron carbonyl. Within about a month the gas contained about $2.4 \mathrm{mg} / 1$ ( $\left.960 \mathrm{ppm}^{*}\right)$ of iron as iron carbony1. Stoffel $1^{15}$ (1914) investigated the reaction between carbon monoxide and finely divided iron (pyrophoric) at gas pressures of $0.5-2 \mathrm{~atm}$ (50 to $200 \mathrm{kPa}$ ) and in the temperature range 20 to $80^{\circ} \mathrm{C}$. He found that adsorbed iron carbonyl on the metal surface lowered the reaction rate drastically, and that the reaction rate was approximately proportional to the square of the carbon monoxide pressure. Mond and Wallis ${ }^{16}$ (1922) reacted pyrophoric iron with carbon monoxide in the pressure range 100-300 atm (10 to $30 \mathrm{MPa}$ ) and in the temperature range 130 to $260^{\circ} \mathrm{C}$, with a reaction time of $2 \mathrm{hr}$. 'l'hey obtained optimum yields at $200^{\circ} \mathrm{C}$ at all pressures.

Miteãs̄ch ${ }^{17}$ (1928) reported that even small amounts of oxygenen strongly repress iron carbonyl formation, whereas hydrogen and ammonia increase the reaction rate. Pichler and Walenda ${ }^{7}$ (1940) investigated in some detail the reaction between carbon monoxide and various alloyed steels, as well as unalloyed carbon steel and cast iron. They worked in the pressure range $150-1000 \mathrm{~atm}$ (15 to $100 \mathrm{MPa}$ ). The extent of carbonyl

\footnotetext{
${ }^{*}$ p.p.m. will be understood as (volume fraction $\times 10^{6}$ ) of the gas
} in question. 
formation was determined by measuring the weight loss of the metal samples under both static and flowing gas conditions.

Their results are interesting and will be discussed in some detail:

1. In agreement with Mond and Wallis ${ }^{16}$ they found that the reaction rate reached a maximum at $200^{\circ} \mathrm{C}$. In these experiments they used granulated, unalloyed, $5-9 \mathrm{~g}$ samples of low-carbon steel with a grain size of 0.15 to $0.30 \mathrm{~mm}$ in a static atmosphere of co with $10 \%$ $\mathrm{N}_{2}$, at a starting pressure of $300 \mathrm{~atm} .(30 \mathrm{MPa}$ ) in a 100-mI autoclave. The reaction time was $48 \mathrm{hr}$.

It is important to note that equilibrium was not reached under these conditions except possibly at $250^{\circ} \mathrm{C}$. The authors did not measure the surface areas of the samples, but one can make an order-ofmagnitude estimate by assuming that the granules were all shaped as cubes of the same size. This gives for a $1 \mathrm{~cm}^{3}$ net volume of sample metal ( $7.8 \mathrm{~g}$ ) a surface area of $2 \mathrm{~m}^{2}$ for a granule edge size of $0.3 \mathrm{~mm}$ and $6 \mathrm{~m}^{2}$ for a granule size of $0.1 \mathrm{~mm}$. Presumably, the ratio surface area/volume for an "average" grain is somewhat larger than for a cube, so that one may assume that the surface areas of their samples were in the range from 5 to $10 \mathrm{~m}^{2}$. This implies, that for a weight loss of about $30 \%$ of an $8-g$ sample, the weight loss per unit surface area would be of the order of $0.5 \mathrm{~g} / \mathrm{m}^{2}$ in $48 \mathrm{hr}$.

2. A most important observation was that the reaction rate depended upon the gas flow rate. Using a 14-mm-ID pressure tube as a reaction chamber at $150 \mathrm{~atm}(15 \mathrm{MPa})$ gas pressure and $200^{\circ} \mathrm{C}$, they observed that the attack increased by a factor of 5.3 for untreated low-carbon steel, and by a factor of 11.2 for "pretreated" samples (i.e., heated to a "yellow glow" and quenched in water), by increasing the gas flow rate from 2 liters/hr up to 100 liters/hr [referred to $1 \mathrm{~atm}$ (0.101 MPa) gas pressure].: Since the cross section of the reaction tube was $1.54 \mathrm{~cm}^{2}$ and the pressure $150 \mathrm{~atm}$ ( $15 \mathrm{MPa}$ ), these flow rates correspond to linear flow rates of 2.5 to $125 \mathrm{~mm} / \mathrm{min}$ at 150 and $200^{\circ} \mathrm{C}$, not counting the reduction in the cross section caused by the sample. F1gure 1 shows a plot of the1r results in their Tables 4 and 5 , in terms of iron loss per hour versus linear flow rate. 


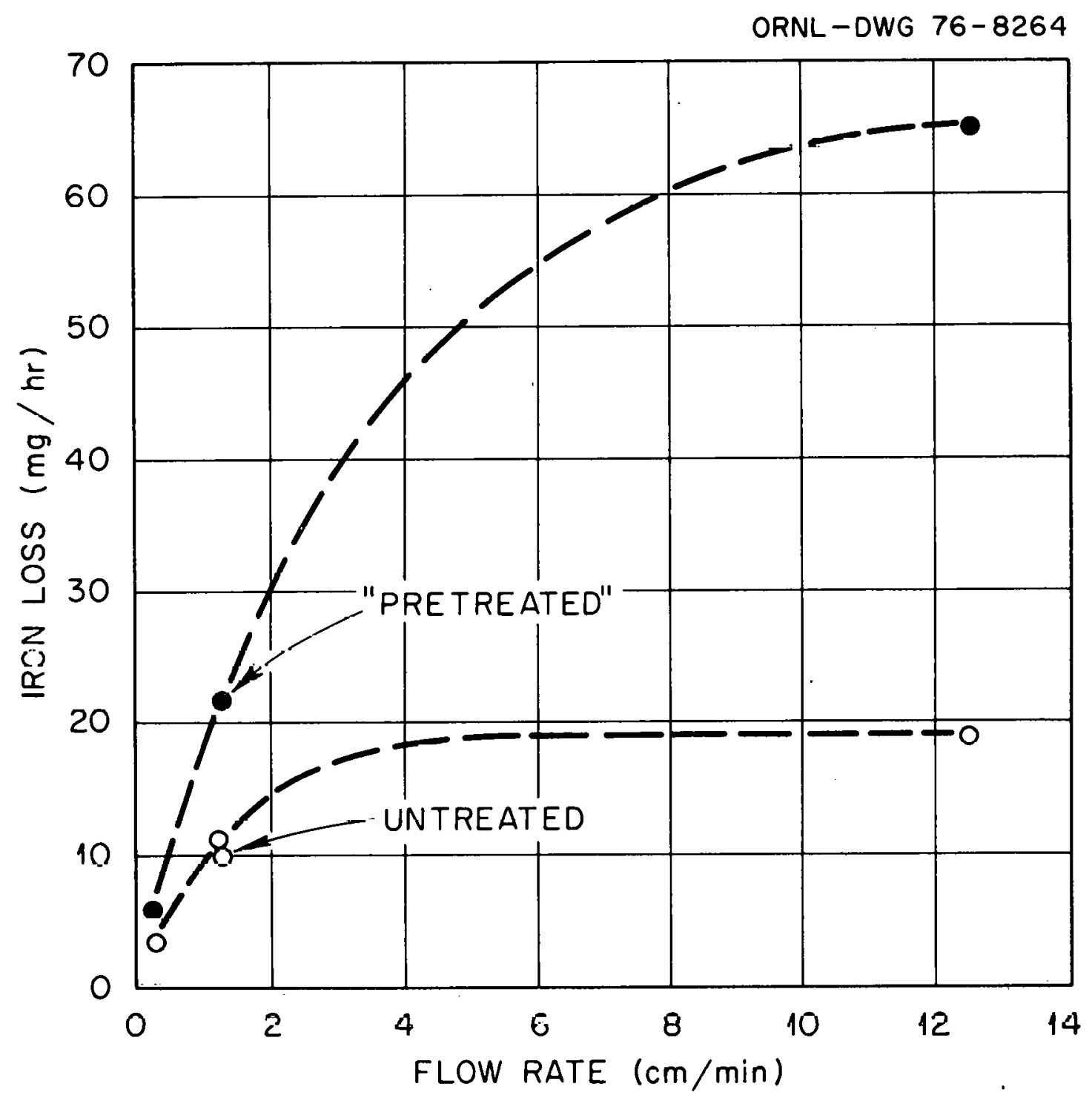

Fig. 1. Attack of Low-Carbon Steel as a Function of Flow Rate. 
These results show that tests on carbonyl formation in static atmospheres will not give information pertinent to conditions with flowing gas. Rather, one must keep flow rates high enough to be sure to be located on the plateau, where the rate of carbonyl formation is invariant with respect to the flow rate. Since the nature of the surface may change with the extent of the (corrosive) attack, thus changing the formation rate, it seems important also to study the time dependence of the carbonyl formation under constant external conditions.

3. There is implicit information in their data that the reaction rate depends on pressure. Their Tables 6 and 7 give the results for the attack by (static) $\mathrm{CO}$, at $200^{\circ} \mathrm{C}$ for four days duration upon various alloyed steels at $300 \mathrm{~atm}$ ( $30 \mathrm{MPa}$ ) (Table 6) and $450 \mathrm{~atm}$ (46 MPa)

- (Table 7). A steel containing $1.22 \% \mathrm{Nb}, 0.15 \% \mathrm{C}$ (test 5 , Table 6; test 16, Table 7) was tested at both pressures. Assuming that the respective samples had the same ratio of surface area to weight, and that the surfaces of the samples were in the same "state", the attack (weight loss/surface area) was 2.04 times larger at $450 \mathrm{~atm}(46 \mathrm{MPa})$ than at $300 \mathrm{~atm}(30 \mathrm{MPa})$. This corresponds to a carbon monoxide pressure dependence of $p_{\mathrm{CO}}^{1 \cdot 76}$. This is in reasonable agreement with Stoffel ${ }^{15}$ who found a pressure dependency of about $p_{\mathrm{CO}}^{2}$ in the $0.5-2 \mathrm{~atm}$ (50-200 kPa) range.

4. By chemical analysis of the carbonyls from an alloy with $5 \%$ nickel, they obtained the ratio $\mathrm{Fe}(\mathrm{CO})_{5} / \mathrm{Ni}(\mathrm{CO})_{4}=95.4 / 4.6$ (i.e., the formation of nickel carbonyl is not preferred).

5. By comparing their $200^{\circ} \mathrm{C}$ data of Tables 2 and 3 with their data in Tahles 6 and 7, one arrives at the conclusion that all alloyed steels tested were much more resistant than the "reference" low-carbon steel they used.

6. The results given in their Table 10 for differing gas compositions are quite interesting. These experiments were conducted with rods $6 \mathrm{~mm}$ diam and $40 \mathrm{~mm}$ long (total surface area $8.1 \mathrm{~cm}^{2}$ ), at $1000 \mathrm{~atm}(100 \mathrm{MPa})$ and $200^{\circ} \mathrm{C}$, with a linear gas flow rate of about $2.5 \mathrm{~mm} / \mathrm{min}$ (at $1000 \mathrm{~atm}, 200^{\circ} \mathrm{C}$ ), 
and for a 400-hr duration. Two different gas mixtures were used, $90 \% \mathrm{CO}, 10 \% \mathrm{~N}_{2}$ and $60 \% \mathrm{H}_{2}, 30 \% \mathrm{CO}, 10 \% \mathrm{~N}_{2}$.

One conclusion that can be drawn from these results is that the carbonyl formation depends upon the nature of the gas mixture. Although the carbon monoxide partial pressure in the $\mathrm{H}_{2}-\mathrm{CO}-\mathrm{N}_{2}$ mixture is only one-third that in the $\mathrm{CO}-\mathrm{N}_{2}$ mixture, some of the alloys were considerably more attacked by the $\mathrm{H}_{2}-\mathrm{CO}-\mathrm{N}_{2}-\mathrm{m}$ ixture due to a catalytic efliect by the hydrogen. However, no uniform trend can be detected.

The results also indicate that high-chromium alloys are quite resistant toward attack in both cases.

If one assumes that the rate of carbonyl formation is proportional to $p^{1 \cdot 76}$, one may extrapolate these data to the conditions of 1000 psi $(7 \mathrm{MPa}), 200^{\circ} \mathrm{C}$. This gives an attack rate of $8.8 \times 10^{-3}$ times the rate at $1000 \mathrm{~atm}$. Taking the surface areas of the samples into consideration, and assuming that the system was in "steady state" during the experiment, this gives a calculated iron loss at 1000 psi and $200^{\circ} \mathrm{C}$ :

$$
\text { Loss }\left(\mathrm{g} \mathrm{m}^{-2} \text { year }{ }^{-1}\right) \approx 240 \Delta w(\mathrm{~g}) \text {, }
$$

where $\Delta w$ is the weight loss in their Table 10. In the worst case reported, this would mean a loss of about $64 \mathrm{~g} \mathrm{~m}^{-2}$ year ${ }^{-1}$, for a $0.5 \%$ Mo, $0.15 \%$ steel. If one assumes that the system was in steady state during the experiment, the weight losses $\Delta w$ listed in their Table 10 expressed as ppm iron carbonyl in the gas, will be

$$
\mathrm{ppm} \approx 167 \Delta w(\mathrm{~g})
$$

In the "worst" case in their Table 10, $\Delta w=0.268 \mathrm{~g}$, so that the carbony 1 content in the gas mixture was about $55 \mathrm{ppm}$. If the same experiment had been run at $1000 \mathrm{psi}(7 \mathrm{MPa}$ ) instead of at $1000 \mathrm{~atm}(100 \mathrm{MPa})$, the gas mixture would have contained about $0.5 \mathrm{ppm}$ carbonyl. 
These somewhat speculative extrapolations indicate that in order to conduct meaningful kinetic experiments at $1000^{\text {p ps }}$ or less, one must be able to determine carbonyl contents in the gas on the parts-per-billion level with a reasonable accuracy. Moreover, it seems to be desirable to keep the ratio (metal surface area)/(gas volume) as large as possible, depending upon the sensitivity of the analytical techniques employed.

Hieber and Geisenberger ${ }^{18}$ (1950) observed that small amounts of sulfur, selenium, or tellurium, especially $\mathrm{H}_{2} \mathrm{~S}$, in the gas enhance the reaction rate between carbon monoxide and iron. In their experiments they used pyrophoric iron at $200^{\circ} \mathrm{C}$ and $200 \mathrm{~atm}(20 \mathrm{MPa}$ ) (initial pressure). Ludlum and Eischens ${ }^{19}$ (1973) reported that the formation of carbonyl by the reaction of carbon monoxide with the components of stainless steel (type 304 ) poses a special problem in the infrared study of adsorbed carbon monoxide because the bands due to carbonyls are found in the same spectral regions as those due to carbon monoxide adsorbed on metals. During 1-hr exposure to carbon monoxide at 700 torr $(93 \mathrm{kPa})$ and room temperature, about $200 \mathrm{~cm}^{2}$ surface area formed about $0.3 \mathrm{mg}$ of adsorbed carbonyls of nickel, iron, and (presumably) chromium. The carbonyls were easily removed by evacuation at $25^{\circ} \mathrm{C}$.

\section{QUANTITATIVE ANALYTTICAL METHODS FOR THE DETERMINATION OF SMALL AMOUNTS OF IRON AND NICKEL CARBONYL IN GASES}

A number of analytical methods are reported in the literature for the quantitative determination of small amounts of iron and nickel carbonyls in gases. Nickel carbonyl and iron carbonyl are extremely toxic. The maximum allowable exposure to nickel carbonyl, $\mathrm{Ni}(\mathrm{CO})_{4}$, determined by an $8-\mathrm{hr}$ weighted average, has been set by the Occupational

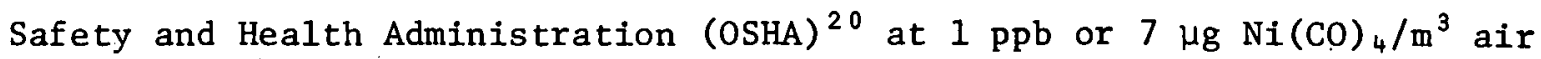
$\left(2.5 \mu \mathrm{Ni} / \mathrm{m}^{3}\right.$ air. $)$, and for the iron carbonyl at $10 \mathrm{ppb}$ or $90 \mu \mathrm{g}$ $\mathrm{Fe}(\mathrm{CO})_{5} / \mathrm{m}^{3}$ air $\left(25 \mathrm{\mu g} \mathrm{Fe} / \mathrm{m}^{3}\right.$ air $)$. 
To be useful in monitoring these low concentrations the analytical method used must respond to much lower concentrations than the maximum allowable value, and be usable even in the presence of other chemicals. It also must have a short response time, especially if the levels of carbonyl change appreciably with time. Since nickel carbonyl is the more common hazard of these two, and also by far the most toxic, the main effort has been put into developing monitoring methods for nickel carbonyl in air.

Wernlund and Cohen ${ }^{20}$ (1975) report that Fourier Transform Infrared Spectroscopy and Plasma Chromatography show promise for monitoring nickel carbonyl. Their plasma chromatograph monitor has a minimum detectable concentration of nickel carbonyl in air of $0.022 \mathrm{ppb}$, lower than the . OSHA limit by a factor of 45. The system time constant was reported to be $2 \mathrm{sec}$. Presumably, their technique should be easily adaptable to iron carbonyl as well.

McDowe $11^{21}$ (1971) described a method for determining nickel carbonyl vapors by infrared spectrophotometry and claims that detectabilities in the range of 1 to $10 \mathrm{ppb}$ should be achievable without great difficulty. However, high partial pressures of $\mathrm{CO}$ can interfere with accurate measurements.

Brief, et al. ${ }^{8,22}(1965,1967)$ evaluated existing wet chemical methods for determining very low levels of nickel and iron carbonyls in gases and found it desirable to develop more sensitive and reliable methods. We have tested their methods as described, and found that they are as sensitive and reliable as reported.

Densham et al. ${ }^{23}$ (1963) reviewed different tests then available for determining nickel and iron carbonyls in gas streams, mainly aimed at the determination of nickel and iron carbonyls in town gas, and they also described new methods that they had developed. Among these, atomic absorption spectroscopy seems to be of special interest to this project, because this method, if applicable, would permit an on-line, practically instantaneous monitoring of iron and nickel carbonyl contents in the gas. Considering that the state of the art in atomic absorption spectroscopy has been greatly improved since 1963, one would assume 
that the sensitivity and accuracy of modern instruments are about an order of magnitude better than that used by Densham et al. Their reported detection limits are $2 \mathrm{ppb}$ for nickel carbony 1 and $10 \mathrm{ppb}$ for iron carbonyl. .

We have tested the atomic absorption spectroscopy method with carbon monoxide containing $44 \mathrm{ppb}$ iron carbonyl, using a Perkin-Elmer 303 spectrophotometer. The results was encouraging with an estimated detection limit of about $0.5 \mathrm{ppb}$. By optimizing the conditions, it should be possible to obtain a detection limit of about $0.1 \mathrm{ppb}$ of iron carbonyl and similar or lower limits for nickel carbonyl. This method is ideally suited to carbonyl reaction ratio studies, since it affords an immediate response to changes in the concentration of metals in the gas. This is not possible for wet chemical methods, where one must collect rather large gas volumes per analysis $(\approx 501$ gas for a $40 \mathrm{ppb}$ iron carbonyl level, and correspondingly larger volumes for lower levels).

Plasma chromatography probably is a much more sensitive method for the analysis of iron carbony1 than atomic absorption spectroscopy. However, good atomic absorption spectrophotometers are commercially readily available and require little time to put into operation, whereas it would require a substantially longer time to establish plasma chromatography as an operative method, for this project.

Fourier transform infrared spectroscopy is not feasible for this project, both from the viewpoint of time as well as cost. In addition, the method may not be suitable in this case because of interference by the carbon monoxide.

\section{PREVENTION METHODS}

Very little direct information exists in the literature about methods for preventing the formation of iron or nickel carbonyl from pipe steels. The usual engineering solutions to the problem seem to 
be either to use high-chromium steels or to line the piping with a material that is inert to the gas mixture and prevents contact of Co with the metal.

Pichler and Walenda ${ }^{7}$ mention the use of copper as liners. Perhaps more interesting is their observation that the attack of carbon monoxide upon the steel seems to be a pure surface area effect, with no special preference to grain boundaries, orientation of the grains, etc. This suggests that even a relatively noncoherent coating of a gas-resistant material may substantially suppress the carbonyl formation, as the carbonyl formation would be directly proportional to the area of the exposed steel surface. For example, a chemical treatment of the steel surface with a copper solution, say copper acetate, might cover the steel surface to $99.9 \%$ or better with copper. In the case of a high-chromium steel, oxidation of the surface to form a coherent chromium oxide layer might prove very effective in preventing even trace levels of carbonyls from being formed.

Clearly a number of effective coatings can be envisioned, so that the deciding factors presumably will be those of cost and lifetime.

\section{CONCLUSIONS}

Literature data demonstrate that the attack upon pipe steels by carbon monoxide in gas mixtures at moderate pressures [1-1000 atm $(0.1-100$ $\mathrm{MPa})$ ] and moderate temperatures $\left(100-300^{\circ} \mathrm{C}\right)$ to form iron and nickel carbonyls are largely governed by kinetics and not by equilibrium thermodynamics. The rate of attack is a function of alloy composition, the surface condition of the metal surface, the gas composition, the gas flow rate, the gas pressure, and the temperature with a maximum at about $200^{\circ} \mathrm{C}$.

Modern analytical instrumental techniques, such as plasma chromatography, Fourier transform infrared spectroscopy, and atomic absorption spectroscopy are all applicable for fast analysis of trace amounts of carbonyls in gases. The most practical method for this project appears to be atomic absorption spectroscopy. 


\section{REFERENCES}

1. GmeZins Handbuch Der Anorganischen Chemie, Vol. 59, Fe[B], p.490 Verlag Chemic. GMBH. Weinheim/Bergstr.

2. N. Irving Sax, Dangerous Properties of Industrial Materials, 4th ed., Van Nostrand-Reinhold, New York, (1975).

3. M. Trautz and W. Badstüber, Z. Electrochem.,35: 799(1929) (In German)

4. A. G. Gilbert and K.G.P. Sulzmann, J. Electrochem. Soc. 121: 832 (1974)

5. L. W. Ross, F. H. Haynie, and R. F. Hochman J. Chem. Eng. Data 9: 339 (1964).

6. V. G. Syrkin, Russ. J. Phys. Chem. 48(12): 1718 (1974) [English translation from Zh. Fiz. Khim. 48: 2927 (1974).

7. H. Pichler and H. Walenda, Brennst. Chem., 21: 133 (1940). (English translation: The John Crerar Library Photoduplication Service.) 35 W. 33rd St., Chicago, IL 60616.

8. R. S. Brief, R. S. Ajemian, and R. G. Confer Am. Inst. Hyg. Ass. J. 28: 21 (1967).

9. L. S. Cooper, A. B. Densham, and M. W. Tanner, Inst. Gas Engr. J. 4: 183 (March 1964).

10. Gmelins Handbuch Der Anorganischen Chemie, Vol. 57, Ni[B], p.794 Verlag Chemic. GMBH. Weinheim/Bergstr, 1966.

11. K. A. Walsh, Physical Properties of Nickez Carbonyz, U.S. A.tomic Energy Commission, Pub1. LA-1649 [1.953/58].

12. B. Suginuma and K. Satozaki, Bulz. Inst. Phys. Chem. Res. Tokyo 21: 432 (1942).

13. A. Ya Kipnis and N. F. Mikhailova Zh. Prikl. Khim. 45:1450 (1972) (English translation: UDC 546. 745: 541. 124.16, 1972 Consultants Bureau).

14. H. E. Roscoe and F. Scudder, Ber. Dtsch. Chem. Ges. 24: 3843 (1891).

15. A. Stoffel, Z. Anorg. Allgem. Chem. 84: 56 (1914).

16. R. L. Mond and A. E. Wallis, J. Chem. Soc., London, 121: 29 (1922).

1\%. A. Mittasch, Z. Angew. Chem. 41: 827 (1928). 
18. W. Hieber and O. Geisenberger, Z. Anorg. Chem. 262: 15 (1950). (In German).

19. K. H. Ludlum and R. P. Eischens Sur. Sci. 40: 397 (1973).

20. R. F. Wernlund and M. J. Cohen Res./Dev. 26(7): 32-35 (1975).

21. R. S. McDowe11, Am. Ind. Hyg. Ass. J. 32: 621 (1971).

22. R. S. Brief, F. S. Venable, and R. S. Ajemian, Ind. Hyg. J. 26: $72(1.965)$.

23. A. B. Densham, P.A.A. Beale and R. Palmer, J. Appl. Chem. (London) 13: 576 (1963). 
ORNL/TM-5499

Distribution

Category UC-90d

INTERNAL DISTRIBUTION

1-2. Central Research Library

3. Document Reference Section

4-8. Laboratory Records Department

9. Laboratory Records, ORNL RC

10. ORNL Patent Office

11. G. M. Adamson

12. S. I. Auerbach

13. R. J. Beaver

14. N. E. Bolton

15. C. R. Brinkman

16-20. J. Brynestad

21. D. A. Canonico

22. J. V. Cathcart

23. H. D. Cochran, Jr.

24. R. A. Cooper

25. R. H. Cooper, Jr.

26. J. E. Cunningham

27. J. H. DeVan

28. J. R. DiStefano

29. R. G. Donnelly

30. W. P. Eatherly

31. M. S. Edwards

32. D. E. Ferguson

33. L. M. Ferris

34. R. C. Forrester III

35. A. P. Fraas

36. W. Fulkerson

37. J. C. Griess, Jr .

38. R. L. Heestand

39-41. M. R. Hill

42. J. M. Holmes
43. H. Inouye

44. J. R. Keiser

45. R. T. King

46. W. R. Laing

47. C. T. Liu

48. W. R. Martin

49. H. E. McCoy

50. R. W. McClung

51. D. L. McE1roy

52. C. J. McHargue

53. J. R. McWherter

54. R. K. Nanstad

55. J. P. Nichols

56. R. E. Pawel.

57. T. W. Pickel

58. W. W. Pitt

59. H. Postma

60. T. K. Roche

61. M. W. Rosenthal

62. Royes Salmon

63. A. C. Schaffhauser

64. C. D. Scott

65. J. E. Selle

66. W. D. Shults

67. G. M. Slaughter

68. J. 0. Stiegler

69. D. B. Trauger

70. J. R. Weir, Jr.

71. J. C. White

72. R. 0. Williams

73. H. L. Yakel

74. C. S. Yust

EXTERNAL DISTRIBUTION

75-90. ERDA, Washington, DC 20545
W. Baker, FER
J. D. Batchelor, CCU
E. L. Clark, CCU
N. P. Cochran, FDP
T. Cox, TER
S. J. Dapkunas, FER
J. Forst, FE
H. Franke1, FE

D. Garret, FDP

S. W. Gouse, FE

W. S. Harmon, FDP

L. Kindley, FER

C. Knudacn; FER

T. K. Lau, FDP

J. Smith, FE

D. K. Stevens, DPR 
EXTERNAL DISTRIBUTION (Continued)

91-95. Morgantown Energy Research Center, P.0. Box 800, Morgantown, WV 26506 Director

96-98. ERDA Pittsburgh Energy Research Center, 4800 Forbes Avenue, Pittsburgh, PA 15213

W. J. McMichaels

W. F. Ilayiles

J, P, Strakey

99. ERDA Fossile Energy Analyst, Office of Congressiona1 Relations, Washington, DC 20545

David 0. Webb

100. ERDA OAK RIDGE OPERATIONS OFFICE, P.O. BOX E, Oak Ridge, TN 37830

Research and Technical Support Division

101-323. ERDA TECHNICAL INFORMATION CENTER, Office of Information Services, P.0. Box 62, Oak Ridge, TN 37830

For distribution as shown in TID 4500 Distribution Category, UC-90d (Coal Conversion and Utilization - Liquefaction) 